\title{
Novel Electrode Materials for Low-Temperature Solid-Oxide Fuel Cells
}

\author{
Annual Progress Report \\ Reporting Period: 24 September 2002 to 23 September 2003 \\ DOE Award Number: DE-FG26-01NT41274 \\ DOE Project Manager: Dr. Lane Wilson \\ Prepared by \\ Shaowu Zha, Luis Aguilar, and Meilin Liu \\ Center for Innovative Fuel Cell and Battery Technologies \\ School of Materials Science and Engineering \\ Georgia Institute of Technology \\ Atlanta, GA 30332-0245
}

Report Issued: December 2003 


\section{DISCLAIMER}

This report was prepared as an account of work sponsored by an agency of the United States Government. Neither the United States Government nor any agency thereof, nor any of their employees, makes any warranty, express of implied, or assumes any legal liability or responsibility for the accuracy, completeness, or usefulness of any information, apparatus, product, or process disclosed, or represents that its use would not infringe privately owned rights. Reference herein to any specific commercial product, process, or service by trade name, trademark, manufacturer, or otherwise does not necessarily constitute or imply its endorsement, recommendation, or favoring by the United States Government or any agency thereof. The views and opinions of authors expressed herein do not necessarily state or reflect those of the United States Government or any agency thereof. 


\begin{abstract}
Fuel cell performance depends strongly on the anode microstructure, which is determined by the anode compositions and fabrication conditions. Four types of anodes with two kinds of $\mathrm{NiO}$ and GDC powders were investigated. By carefully adjusting the anode microstructure, the GDC electrolyte/anode interfacial polarization resistances reduced dramatically. The interfacial resistance at $600^{\circ} \mathrm{C}$ decreased from $1.61 \Omega \mathrm{cm}^{2}$ for the anodes prepared using commercially available powders to $0.06 \Omega \mathrm{cm}^{2}$ for those prepared using powders derived from a glycine-nitrate process. The critical issues facing the development of economically competitive SOFC systems include lowering the operation temperature and creating novel anode materials and microstructures capable of efficiently utilizing hydrocarbon fuels. Anode-supported SOFCs with an electrolyte of $20 \mu \mathrm{m}$-thick Gd-doped ceria (GDC) were fabricated by co-pressing, and both $\mathrm{Ni}$ and $\mathrm{Cu}$-based anodes were prepared by a solution impregnation process. At $600^{\circ} \mathrm{C}$, SOFCs fuelled with humidified $\mathrm{H}_{2}$, methane, and propane, reached peak power densities of 602,519 , and 433 $\mathrm{mW} / \mathrm{cm}^{2}$, respectively. Both microstructure and composition of the anodes, as fabricated using a solution impregnation technique, greatly influence fuel cell performance. Although steam reforming or partial oxidation is effective in avoiding carbon deposition of hydrocarbon fuels, it increases the operating cost and reduces the energy efficiency. A catalyst (1\%wt Pt dispersed on porous Gd-doped ceria) for pre-reforming of propane was developed with relatively low steam to carbon $(\mathrm{S} / \mathrm{C})$ ratio $(\sim 0.5)$, coupled with direct utilization of the reformate in low-temperature SOFCs. Propane was converted to smaller molecules during pre-reforming, including $\mathrm{H}_{2}, \mathrm{CH}_{4}, \mathrm{CO}$, and $\mathrm{CO}_{2}$. A peak power density of $247 \mathrm{~mW} / \mathrm{cm}^{2}$ was observed when pre-reformed propane was directly fed to an SOFC operated at $600^{\circ} \mathrm{C}$. No carbon deposition was observed in the fuel cell for a continuous operation of 10 hours at $600^{\circ} \mathrm{C}$.
\end{abstract}




\section{TABLE OF CONTENTS}

ANNUAL PROGRESS REPORT




\section{LIST OF GRAPHICAL MATERIALS}

Table 1. Sources of precursor powders and firing temperature....................15

Figure 1. SEM photograph of an electrolyte-supported fuel cell ...................15

Figure 2. Cell voltages and power densities for FC-1 to FC4 ....................

Figure 3. Peak power densities for cells FC-1 to FC-4 ..................... 17

Figure 4. Open circuit voltages of cells FC-1 to FC-4 ......................... 17

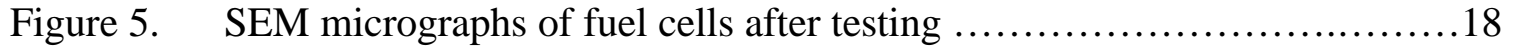

Figure 6. NiGDC anode-supported SOFC ....................................19

Figure 7. Cell performances under hydrocarbon fuels............................ 19

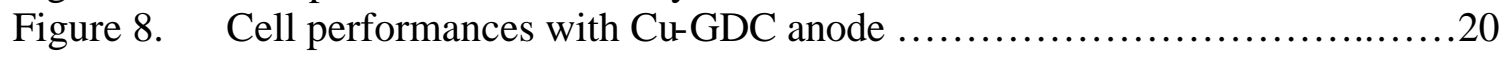

Figure 9. Mass spectrum of reformed propane on catalyst Pt-GDC $\ldots \ldots \ldots \ldots \ldots \ldots . . . .21$

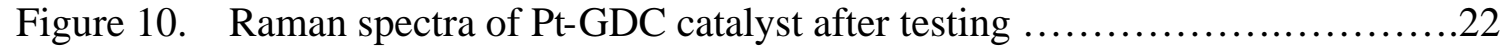

Figure 11. Cell performances under pre-reformed propane $\ldots \ldots \ldots \ldots \ldots \ldots \ldots \ldots \ldots . . .22$ 


\section{INTRODUCTION}

Fuel cells have emerged as a leading technology to provide power sources in an efficient manner. Solid oxide fuel cells, in particular, have the potential to be among the cleanest, most efficient, and versatile technologies for energy conversion. When cleaned coal gas is used as the fuel, it can convert more than $55 \%$ of the energy in its fuel source directly to electricity. It is possible to reach $85 \%$ overall energy efficiencies when the highquality waste heat from the electrochemical processes is recovered. SOFC emits no pollutants and as much as 65\% less carbon dioxide (a greenhouse gas) than a conventional coal-burning plant. ${ }^{1}$

It is the interfacial resistances that limit the performance of SOFCs at temperatures below $550^{\circ} \mathrm{C}$. With continuous progress in fabrication of thin-film electrolyte membranes, ${ }^{2}$ the performance of a new generation of solid-state fuel cells, the target system for SECA, will be determined essentially by the properties of the interfaces. To achieve the goals of the Vision 21 coal-based power plants or to enhance the performance of SOFC at low temperatures, the interfacial resistance of SOFCs must be dramatically reduced.

The objective of this project is to develop novel electrode materials for SOFCs to be operated at low temperatures in order to significantly reduce the cost of SOFC technology. More specifically, the technical objectives include

- To characterize the microscopic features of composite mixed-conducting electrodes and correlate with the ionic, electronic, and ambipolar transport properties as well as with the catalytic activities for pertinent electrochemical reactions;

- To gain a profound understanding of the principles of composite mixed-conducting electrodes, including simultaneous transport of ionic and electronic defects in the solid mixed conductor (influenced primarily by the defect structure), gas transport through the pores of the mixed conductor (influenced mainly by the pore structure), and the reaction kinetics at the mixed conductor/gas interface (influenced mostly by the surface structures and catalytic properties);

- To minimize interfacial polarization resistances through processing modifications, microstructure improvements, and new materials development 


\section{EXECUTIVE SUMMARY}

Four types of anodes have been prepared on $\mathrm{Ce}_{0.9} \mathrm{Gd}_{0.1} \mathrm{O}_{1.95}$ (GDC) electrolyte pellets with two kinds of $\mathrm{NiO}$ and GDC powders to investigate the effect of microstructure on electrochemical performance of NiGDC composite anodes. The anode/electrolyte interfacial polarization resistances are characterized using impedance spectroscopy under open circuit conditions. The results show that the cell performance depends strongly on the anode microstructure, which in turn is determined by the anode compositions and fabrication conditions. By carefully adjusting the anode microstructure, the GDC electrolyte/anode interfacial polarization resistances have been dramatically reduced. For example, the interfacial resistance at $600{ }^{\circ} \mathrm{C}$ was decreased from $1.61 \Omega \mathrm{cm}^{2}$ for the anodes prepared using commercially available powders to $0.06 \Omega \mathrm{cm}^{2}$ for those prepared using powders derived from a glycine-nitrate process.

The critical issues facing the development of economically competitive SOFC systems include lowering the operation temperature and creating novel anode materials and microstructures capable of efficiently utilizing hydrocarbon fuels. In this work, we tried to develop more efficient anodes for direct utilization of methane and propane in lowtemperature SOFCs. Hydrocarbon fuels such as methane and propane were successful fuels for operating at low temperatures. For cells with a Ni-GDC based anode and a thin GDC electrolyte, the maximum power density achieves 519 , and $433 \mathrm{~mW} / \mathrm{cm}^{2}$ fuelled with humidified methane, and propane at $600{ }^{\circ} \mathrm{C}$ without carbon deposits. A novel method by applying co-pressing and ion impregnation process was used to fabricate thin electrolyte SOFCs with $\mathrm{Cu}-\mathrm{GDC}$ based anode. The initial results, running on propane at $600{ }^{\circ} \mathrm{C}$, were exciting, showing a great future for direct utilization of hydrocarbon fuels in low-temperature SOFCs. Since the performance of single cells fueled with $\mathrm{C}_{3} \mathrm{H}_{8}$ is dramatically lower than that fueled with $\mathrm{CH}_{4}$ or $\mathrm{H}_{2}$, pre-reforming of $\mathrm{C}_{3} \mathrm{H}_{8}$ (or other higher hydrocarbons) to $\mathrm{CH}_{4}, \mathrm{H}_{2}$, and $\mathrm{CO}$, may significantly improve fuel cell performance. Results also indicate that both microstructure and composition of the anodes, as fabricated using a solution impregnation technique, greatly influence fuel cell performance.

Although steam reforming or partial oxidation is effective in avoiding carbon deposition of hydrocarbon fuels, it increases the operating cost and reduces the energy efficiency. Based on our previous results of low-temperature SOFC running on hydrocarbon fuels, a catalyst (1\%wt Pt dispersed on porous Gd-doped ceria) was developed for pre-reforming of propane with relatively low steam to carbon $(\mathrm{S} / \mathrm{C})$ ratio $(\sim 0.5)$, coupled with direct utilization of the reformate in low-temperature SOFCs. Propane was converted to smaller molecules during pre-reforming, including $\mathrm{H}_{2}, \mathrm{CH}_{4}, \mathrm{CO}$, and $\mathrm{CO}_{2}$. A peak power density of $247 \mathrm{~mW} / \mathrm{cm}^{2}$ was observed when pre-reformed propane was directly fed to an SOFC operated at $600^{\circ} \mathrm{C}$. No carbon deposition was observed in the fuel cell for a continuous operation of 10 hours at $600^{\circ} \mathrm{C}$. These results imply that pre-reforming could greatly enhance the performance of low-temperature SOFCs that run on higher hydrocarbon fuels. 


\section{EXPERIMENTAL}

The most effective approach to creation of novel electrodes/interfaces of minimal resistance is to use porous mixed ionic-electronic conductors (MIECs) with mesoporous surfaces. MIECs ${ }^{3}$ allow simultaneous transport of both ionic and electronic defects, and the use of an MIEC as electrode may extend the active reaction sites from traditional triple-phase boundaries (TPBs) to the entire MIEC/gas interface, which can be orders of magnitude larger than the TPBs. ${ }^{4}$ The degree of this extension depends critically on the rate of defect transport through the solid MIEC, gas transport through the pores in the MIEC, and the catalytic activity of interfaces. While macro-pores (on the order of microns) promote rapid gas transport, meso- or nano-pores provide extremely high surface areas and high catalytic activity for electrode reactions. It is thus anticipated that macro-porous MIEC electrodes with meso-porous surfaces have great potential to redefine solid-state fuel cells at low temperatures. Successful creation of mesoporous MIEC electrodes with flexibility in composition and pore structure, and hence in electrical, transport, and catalytic properties, will create exciting opportunities in advancing not only low-temperature SOFCs but also other relevant systems such as membranes for gas separation, reforming of hydrocarbon fuels, and coal gas clean up.

Anode Materials: In a $\mathrm{NiGDC}$ composite anode, $\mathrm{Ni}$ acts as both the catalyst and electronic conducting phase, while GDC mainly acts as a matrix to support the catalyst and prohibit the metal from agglomeration under operating conditions. It is believed that ceria can also improve the anode catalytic activity, especially in SOFCs using hydrocarbon fuels ${ }^{5}$. It has been demonstrated that the length of the triple-phase boundary correlates well with the reaction rate for electrochemical oxidation of hydrogen ${ }^{6}$; thus, the extension of the TPB becomes a determining factor in improving anode performance. This can be achieved mainly by optimizing the microstructure of the cermet anode through the adjustment of powder morphologies and particle sizes for the precursor $\mathrm{NiO}$ and ceria, and/or developing a favorable electroding process.

Direct Utilization of Hydrocarbons: Internal steam reforming is a typical approach to operate SOFCs on hydrocarbon fuels. A steam-to-carbon ratio of $>2: 1$ is often used to prevent carbon deposits at the anode. Apparently, however, this method will introduce larger operation cost, and yield lower energy efficiency to the whole fuel cell system. A more promising way of directly using hydrocarbon fuels has recently surfaced. Carbon deposits were suppressed by using anode compositions that do not catalyze hydrocarbon cracking, especially running SOFCs at relatively low temperatures. $\mathrm{Cu}$-ceria/doped ceria is found to be one possible anode material used for direct utilization of hydrocarbon fuels in SOFCs ${ }^{7}$, because it is relatively inert to hydrocarbon reactions, particularly cracking, compared to Ni. SOFCs operating in this way at reduced temperatures $\left(<800{ }^{\circ} \mathrm{C}\right)$ provide useful power densities with hydrocarbon fuels without addition of significant amount of steam, $\mathrm{CO}_{2}$, or $\mathrm{O}_{2}{ }^{8,9}$. However, $\mathrm{Cu}$ or $\mathrm{CuO}$ has a low melting point that makes it difficult to apply conventional ceramic processing methods to fabricate $\mathrm{Cu}$-containing SOFCs. In this study, we developed new anode materials for direct oxidation of methane and propane in low-temperature SOFCs. Anode-supported SOFCs with a $20 \mu \mathrm{m}$ Gd-doped 
ceria electrolyte were fabricated by co-pressing, and both $\mathrm{Ni}$ and $\mathrm{Cu}$-based anodes are prepared by a solution impregnation process.

Pre-reforming of Propane: Pre-reforming, which is often an additional process step for steam reforming, can convert heavier hydrocarbons to a mixture of smaller molecules such as $\mathrm{CH}_{4}, \mathrm{H}_{2}$, and carbon oxides at low temperatures ${ }^{10}$. Therefore, it is possible to reduce the steam/carbon ratio dramatically by applying a pre-reforming process, compared with a general steam reforming process. Moreover, previous results ${ }^{11}$ demonstrated that methane could be directly used as fuel for NiGDC anode-based SOFCs at low temperatures $\left(<650^{\circ} \mathrm{C}\right)$ without carbon deposition. Thus, pre-reforming could be a crucial step towards effective utilization of carbon-containing fuels in lowtemperature SOFCs. In this study, we will develop novel catalysts for pre-reforming of propane, coupled with direct utilization of the reformate in low-temperature SOFCs. 


\section{RESULTS AND DISCUSSION}

Ni-GDC anodes were fabricated on GDC electrolyte supported fuel cells (FC-1 to FC-4, Table 1). Shown in Figure 1 is the typical cross-sectional view of a single fuel cell. All of the single cells were made from the same batch of electrolyte discs with thickness of $\sim 210 \mu \mathrm{m}$. The cathodes were similarly all derived from the same batch of paste (SSC/GDC $=70: 30$ in weight) and were fabricated by a screen-printing process with a final firing temperature of $1000{ }^{\circ} \mathrm{C}$ for 2 hours. The only difference in the test fuel cells was the anode precursor powders and corresponding microstructure. The four test cells are named for their anode powder derivations, namely C-C, G-C, C-G, and G-G for the $\mathrm{NiO}$ and GDC powders respectively from either commercial sources (C) or GNP preparation $(\mathrm{G})$.

Shown in Figure 2 (a-d) are the cell voltage and power density as a function of current density for the different anode-based fuel cells. When applying GNP-NiO and GNP-GDC composite as anode (FC-4), the fuel cell demonstrates very high performances, as shown in Figure 2 (d). For example, the open circuit voltages (OCVs) are 0.93 and $0.84 \mathrm{~V}$, while the maximum power densities are 220 and $402 \mathrm{~mW} / \mathrm{cm}^{2}$ at 600 and $700{ }^{\circ} \mathrm{C}$, respectively. When reducing the operation temperature to $500{ }^{\circ} \mathrm{C}$, the $\mathrm{OCV}$ increases to $1.00 \mathrm{~V}$, closer to the theoretical electromotive force, $1.14 \mathrm{~V}\left(3 \mathrm{vol} . \% \mathrm{H}_{2} \mathrm{O}-\mathrm{H}_{2}\right.$ and air fed as the fuel and the oxidant gas). As expected, the internal electrical shorting caused by partial electronic conduction in GDC becomes less severe for thicker GDC electrolyte at lower temperatures.

Further, it can be seen from Figure 2 that the performance of these fuel cells depends strongly on the anode when keeping other conditions identical. The peak power density and open circuit voltage vs temperature for FC- 1 to FC-4 are summarized in Figures 3 and 4 for comparison. FC-4 with a G-G anode, i.e., both $\mathrm{NiO}$ and GDC in the anode are synthesized by glycine-nitrate process, has the highest power density among the four fuel cells tested. FC-3 with a $\mathrm{C}-\mathrm{G}$ anode, where the $\mathrm{NiO}$ precursor is a commercial product and GDC is synthesized by GNP, has the lowest power output. The power densities of FC-3 are only about $1 / 5$ of those of FC-4 cell over the temperature range studied. In the meantime, FC-1 and FC-2 cells with anode components of $\mathrm{C}-\mathrm{C}$ and $\mathrm{G}-\mathrm{C}$ have similar peak power densities but only about one-half of those of the FC-4 cell. The open circuit voltages of FC-1 to FC-4 reveal a similar trend. FC-4 has the highest OCVs while the FC-3 cell has the lowest values in the temperature range studied. For example, the OCVs are 0.84 and $0.77 \mathrm{~V}$ for FC-4 and FC-3 at $700{ }^{\circ} \mathrm{C}$, respectively. The $\mathrm{OCV}$ depends on the interfacial polarization resistances for cells based on electrolyte of mixed conduction

such as ceria-based electrolytes ${ }^{12,13}$. Thus, different OCV values are closely correlated to different power densities, which are determined by the various anode configurations and anode/electrolyte interfacial polarization resistances.

Shown in Figure 5 are the cross-sectional views of the electrolyte and the anode after fuel cell performance testing. The relative density of the GDC electrolyte is about $95 \%$. Both $\mathrm{NiO}$ and GDC grains coarsened during firing. As can be seen from Figures 5(b) and (d), the porous anodes for FC- 2 and FC- 4 have similar morphologies since they all contain 
the same glycine-nitrate derived $\mathrm{NiO}$. The anode of cell FC-4 has a smaller average grain size and a more homogenous microstructure than FC-2. On the other hand, FC-1 and FC3, fabricated from coarser $\mathrm{NiO}$ precursor powder, have substantially different morphologies. Though some larger Ni grains are visible in the FC-1 C-C anode (see Figure 5(a)), the two phases (Ni and GDC) are uniformly distributed and well connected, which is desirable for anodic reactions and electronic conduction. For the anode of FC-3, it is seen that the finer GNP-derived powders tend to aggregate more easily, forming islands of isolated GDC grains. In forming these islands, the fine particles shrank substantially to leave larger pores in the anode as seen in Figure 5(c). Accordingly, these GDC "islands" and larger pores resulted in poor Ni distribution.

It is known that fine grain size, large surface area, adequate porosity, and sufficient nickel content in the anode are essential to achieve high performance. For a $\mathrm{Ni}$-GDC anode, the distribution and contact area between $\mathrm{Ni}$ and GDC particles are also of great importance. The nickel grains in a $\mathrm{NiGDC}$ cermet are regarded as the active sites for $\mathrm{H}_{2}$ oxidation, while the GDC grains act as a mechanical support for nickel and the supplier of oxygen ions in addition to their partial role in hydrogen oxidation. Ideally, the two phases of nickel and GDC should be intimately mixed to increase the triple phase boundary length. Further, the composite anode should be sufficiently porous to allow rapid gas transport. The microstructure of the anode in FC-4 satisfies all the requirements for high performance. In contrast, the larger $\mathrm{Ni}$ and GDC grains and the poor distribution observed in the FC-3 anode are responsible for the high anode/electrolyte interfacial resistance, resulting in much lower fuel cell performance compared with cell FC-4. It is also found that the anodes of FC-3 always had poor adhesion with the electrolyte layer after cell testing. When the cell was removed from the testing apparatus, the FC-3 anodes were easily peeled off or even delaminated from the electrolyte layer. In contrast, this has never occurred on the other fuel cells tested.

GDC-Based Low Temperature SOFCs Powered by Hydrocarbon Fuels: Figure 6 displays a typical cross-sectional micrograph of a NiGDC anode-supported SOFC with a thin GDC electrolyte layer. The anode and electrolyte was fabricated by co-pressing process. This micrograph shows a dense, $20 \mu \mathrm{m}$ thin GDC electrolyte sandwiched between the porous anode and cathode layers. The electrolyte film thickness can be controlled during co-pressing with the amount of GDC foamy powder synthesized by glycine-nitrate process, due to its rather low-tapped density.

The performance was measured at temperatures between 500 and $650^{\circ} \mathrm{C}$. Three kinds of fuels, hydrogen, methane, and propane, are fed in turn. Figure 7 shows the cell voltage and power density as a function of current density for the three fuels. Extremely high power densities were obtained when hydrogen and methane were used as fuels at operating temperatures below $650^{\circ} \mathrm{C}$. The maximum power densities are 602 and 519 $\mathrm{mW} / \mathrm{cm}^{2}$ with OCVs of 0.852 and $0.846 \mathrm{~V}$ at $600^{\circ} \mathrm{C}$ for hydrogen and methane, respectively. At all measuring temperatures, the OCV when using methane as fuel is a little lower than that of using hydrogen, while the maximum power density for methane is about $20 \%$ lower than for hydrogen. This may be due to the different catalytic activity of 
$\mathrm{Ni}$ towards hydrogen and methane. When using methane, the cell shows apparent concentration polarization at higher current density in contrast with applying hydrogen, especially when the operation temperature goes down as clearly shown in Figure 7(b). The cell exhibits a quite different performance compared to hydrogen and methane when using propane fuel. The cell achieves a maximum power density of $433 \mathrm{~mW} / \mathrm{cm}^{2}$ with OCV value of $0.830 \mathrm{~V}$ for propane at $600^{\circ} \mathrm{C}$; however, the electrical output drops dramatically with a decrease in operating temperature.

Two cells were operated on methane and propane fuels separately to investigate the carbon deposition with temperature and time. No carbon deposits were visible while running on methane for more than $50 \mathrm{~h}$. In contrast, when running on propane at $600^{\circ} \mathrm{C} \mathrm{a}$ large amount of black carbon was deposited on the anode surface after only $3 \mathrm{~h}$. The results indicate that propane will crack to amorphous carbon in the $\mathrm{NiGDC}$ anode surface. On the other hand, nickel does not crack methane below $650^{\circ} \mathrm{C}$, due to the much more thermodynamically stable $\mathrm{C}-\mathrm{H}$ bonds in methane than $\mathrm{C}-\mathrm{C}$ bonds in propane. According to the results of Ref. [7,9], direct oxidation electrochemical oxidation may be the primary anode reaction, although further investigation is needed to verify it. Therefore, methane is a possible hydrocarbon gas that can be used directly as fuel for low-temperature SOFCs based on NiGDC anode.

Shown in Figure 8 shows are plots of the potential $v s$. current density for an SOFC prepared using a $\mathrm{Cu}$-based anode (Cu-GDC) and a $20 \mu \mathrm{m}$ - thick GDC electrolyte. When $\mathrm{H}_{2}, \mathrm{CH}_{4}$ and $\mathrm{C}_{3} \mathrm{H}_{8}$ were used as fuels, the maximum power densities at $600^{\circ} \mathrm{C}$ achieved were 265,200 and $170 \mathrm{~mW} / \mathrm{cm}^{2}$ with $\mathrm{OCVs}$ of $0.796,0.801$ and $0.782 \mathrm{~V}$, respectively. The power density for propane at such low temperature as $600^{\circ} \mathrm{C}$ is believed to be the highest for SOFCs using $\mathrm{Cu}$-based anode having been reported so far. Although both maximum power density and $\mathrm{OCV}$ at the same operating temperature are lower than $\mathrm{Ni}$ GDC based SOFCs fabricated by the co-pressing method discussed in the previous section, no carbon deposition was observed for this $\mathrm{Cu}$ based fuel cell when using propane fuel. Copper can thus be used to replace Ni because it is relatively inert to hydrocarbon reactions, particularly cracking. Doped ceria is feasible because of its wellknown activity for hydrocarbon oxidation.

Pre-reforming of propane was investigated using a composite of gadolinium dopedceria and $1 \% \mathrm{wt} \mathrm{Pt}$ as the catalyst. The catalyst has good porous microstructure with an average particle size of about $0.2 \mu \mathrm{m}$ and BET surface area of $5 \mathrm{~m}^{2} / \mathrm{g}$. After the running of pre-reforming, there were no observable changes in morphology from the as-prepared sample. Shown in Figure 9(a) are the mass spectra of the outlet gas when $\mathrm{C}_{3} \mathrm{H}_{8}$ and steam (at $\mathrm{S} / \mathrm{C}=0.5$ ), diluted by argon were fed to the catalyst bed with $1 \%$ wt Pt-GDC as the catalyst at $650^{\circ} \mathrm{C}$ for pre-reforming. In order to examine the background of the prereforming process due to thermal cracking, the same inlet gas stream was also fed to the alumina tube without catalyst. The corresponding mass spectra were shown in Figure 9(b). It can be clearly seen that only a small amount of propane was converted to smaller molecules (e.g., $\mathrm{H}_{2}, \mathrm{CH}_{4}$ and $\mathrm{CO}$ ) in the blank runs. In contrast, when $1 \%$ wt Pt-GDC was used as the catalyst at $650^{\circ} \mathrm{C}$, nearly all propane was converted to $\mathrm{H}_{2}, \mathrm{CH}_{4}, \mathrm{CO}$, and 
$\mathrm{CO}_{2}$. The composition ratios of $\mathrm{CH}_{4}, \mathrm{H}_{2}, \mathrm{CO}$, and $\mathrm{CO}_{2}$ were 2.5:1.5:1:0.25, as estimated from the mass spectra shown in Figure 2(a). It is also noted that the S/C ratio was very low ( 0.5), which shows that the pre-reforming process using $1 \%$ wt Pt-GDC as the catalyst can result in energy savings. It is believed that both Pt and GDC are activated to be excellent catalysts for the pre-reforming of propane at elevated temperatures. Additionally, it is believed that the catalytic performance of platinum is enhanced by the ionic conduction of doped ceria in a humidified atmosphere. Because of the combined effect of ceria and platinum, propane dissociates on platinum and reacts with oxygen ions adsorbed on doped ceria ${ }^{14,15}$. After operation for $6 \mathrm{~h}$, a small amount of carbon deposition was observed only in the area close to the entrance of the gas inlet. There are no observable differences in the XRD patterns of the Pt-GDC catalyst before and after pre-reforming operation. Shown in Figure 10 are Raman spectra of the catalyst samples before and after the pre-reforming operation. While a weak and broad carbon peak is observed for the catalyst sample taken from the area where the gas (propane and steam) enter the reactor after the pre-reforming operation, there was no observable carbon peak for the catalyst taken from other parts of the reactor after the pre-reforming operation.

Figure 11 shows the cell voltages and power densities versus current density for a typical anode-supported fuel cell operated at $600^{\circ} \mathrm{C}$, with a cell configuration of $\mathrm{NiGDC}$ (anode)/GDC/Smb.5 $\mathrm{Sr}_{0.5} \mathrm{CoO}_{3}$-GDC (cathode). While the cathode was exposed to stationary air, the anode was fed with different fuels: hydrogen $\left(10 \mathrm{ml} / \mathrm{min} \mathrm{H}_{2}+10\right.$ $\mathrm{ml} / \mathrm{min} \mathrm{Ar})$, propane $\left(5 \mathrm{ml} / \mathrm{min} \mathrm{C}_{3} \mathrm{H}_{8}+20 \mathrm{ml} / \mathrm{min} \mathrm{Ar}\right)$, and pre-reformed propane. Each datum point was recorded about $30 \mathrm{~min}$ after the cell reached the steady state. As shown in Figure 11, open-circuit voltages (OCVs) of $0.855,0.849$, and $0.836 \mathrm{~V}$ were observed at $600^{\circ} \mathrm{C}$ for $\mathrm{H}_{2}$, pre-reformed gas, and propane, respectively. The lower OCV values compared to Nernst potentials were due to the partial electronic conduction of GDC electrolyte, which became more severe when thin electrolyte membrane was used ${ }^{12}$. In this study, the thickness of the electrolyte was about $20 \mu \mathrm{m}$. The maximum power densities were 258, 247, and $205 \mathrm{~mW} / \mathrm{cm}^{2}$ for the cell using three kinds of fuels, respectively. These results show that when the pre-reformed gas was used directly as fuel, the fuel cell performances were similar to those using hydrogen as fuel. Moreover, no carbon deposit was observed after continuous operation for more than $10 \mathrm{~h}$ using the pre-reformed propane as the fuel, which was consistent with our previous result when methane was fed directly as fuel to the fuel cells ${ }^{11}$. In contrast, when propane was directly used as the fuel, the fuel cell performance was relatively low and degraded quickly due to carbon deposition. For example, the peak power density reduced to only $140 \mathrm{~mW} / \mathrm{cm}^{2}$ after running on propane for $10 \mathrm{~h}$, while the values for fuel cells running on diluted $\mathrm{H}_{2}$ and pre-reformed propane remained stable during the 10 hours operation. 


\section{CONCLUSIONS}

GDC electrolyte-supported fuel cells were fabricated and tested at intermediate temperatures. Impedance spectra showed that the resistances of anode/electrolyte interfaces depend strongly on the anode microstructure, which in turn was essentially determined by the compositions and fabrication conditions. Anodes consisting of finer precursor powders of $\mathrm{NiO}$ and GDC exhibit excellent performances. The anode/electrolyte interfacial resistances are about 0.06 and $0.05 \Omega \mathrm{cm}^{2}$, translating to maximum power densities of 220 and $402 \mathrm{~mW} / \mathrm{cm}^{2}$ at 600 and $700^{\circ} \mathrm{C}$, respectively, for a fuel cell based on a $210 \mu \mathrm{m}$ thick GDC electrolyte. Further, substantial decrease in performance was observed when the firing temperature of the anodes was increased from 1250 to $1350^{\circ} \mathrm{C}$.

Two types of anode-supported fuel cells were fabricated by co-pressing and by a combination method of co-pressing and ion impregnation. Hydrocarbon fuels such as methane and propane were successful fuels for operating at low temperatures. For cells with a $\mathrm{NiGDC}$ based anode and a thin GDC electrolyte, the maximum power density achieves $519 \mathrm{~mW} / \mathrm{cm}^{2}$ at $600^{\circ} \mathrm{C}$ without carbon deposits. A novel method by applying copressing and ion impregnation process was used to fabricate thin electrolyte SOFCs with $\mathrm{Cu}-\mathrm{GDC}$ based anode. The initial results, running on propane at $600^{\circ} \mathrm{C}$, were exciting, showing a great future for direct utilization of hydrocarbon fuels in low-temperature SOFCs. Since the performance of single cells fueled with $\mathrm{C}_{3} \mathrm{H}_{8}$ is dramatically lower than that fueled with $\mathrm{CH}_{4}$ or $\mathrm{H}_{2}$, pre-reforming of $\mathrm{C}_{3} \mathrm{H}_{8}$ (or other higher hydrocarbons) to $\mathrm{CH}_{4}$, $\mathrm{H}_{2}$, and $\mathrm{CO}$, may significantly improve fuel cell performance.

Lowering the operation temperature and effectively utilizing practical fuels are two critical issues facing the development of economically competitive solid oxide fuel cell (SOFC) systems. Although steam reforming or partial oxidation is effective in avoiding carbon deposition of hydrocarbon fuels, it increases the operating cost and reduces the energy efficiency. A catalyst (1 \%wt Pt dispersed on porous Gd-doped ceria) was developed for pre-reforming of propane with relatively low steam to carbon (S/C) ratio $(\sim 0.5)$, coupled with direct utilization of the reformate in low-temperature SOFCs.

Propane was converted to smaller molecules during pre-reforming, including $\mathrm{H}_{2}, \mathrm{CH}_{4}$, $\mathrm{CO}$, and $\mathrm{CO}_{2}$. A peak power density of $247 \mathrm{~mW} / \mathrm{cm}^{2}$ was observed when pre-reformed propane was directly fed to an SOFC operated at $600^{\circ} \mathrm{C}$. No carbon deposition was observed in the fuel cell for a continuous operation of 10 hours at $600^{\circ} \mathrm{C}$. These results imply that pre-reforming could greatly enhance the performance of low-temperature SOFCs that run on higher hydrocarbon fuels. 


\section{Tables and Figures}

Table 1. Sources of precursor powders and firing temperature of the anode samples (65 wt.\% $\mathrm{NiO}$ and 35 wt.\% GDC).

\begin{tabular}{c|c|c|c}
\hline Fuel cell & Anode component & $\begin{array}{c}\text { Firing } \\
\text { temperature }\end{array}$ & $\begin{array}{c}\text { Anode } \\
\text { abbreviation }\end{array}$ \\
\hline FC-1 & Comm-NiO Comm-GDC & & C-C \\
FC-2 & GNP-NiO Comm-GDC & $1250{ }^{\circ} \mathrm{C}$ & G-C \\
FC-3 & Comm-NiO GNP-GDC & & C-G \\
FC-4 & GNP-NiO GNP-GDC & & G-G \\
\hline FC-12 & Comm-NiO Comm-GDC & $1350{ }^{\circ} \mathrm{C}$ & C-C \\
FC-42 & GNP-NiO GNP-GDC & & G-G \\
\hline
\end{tabular}

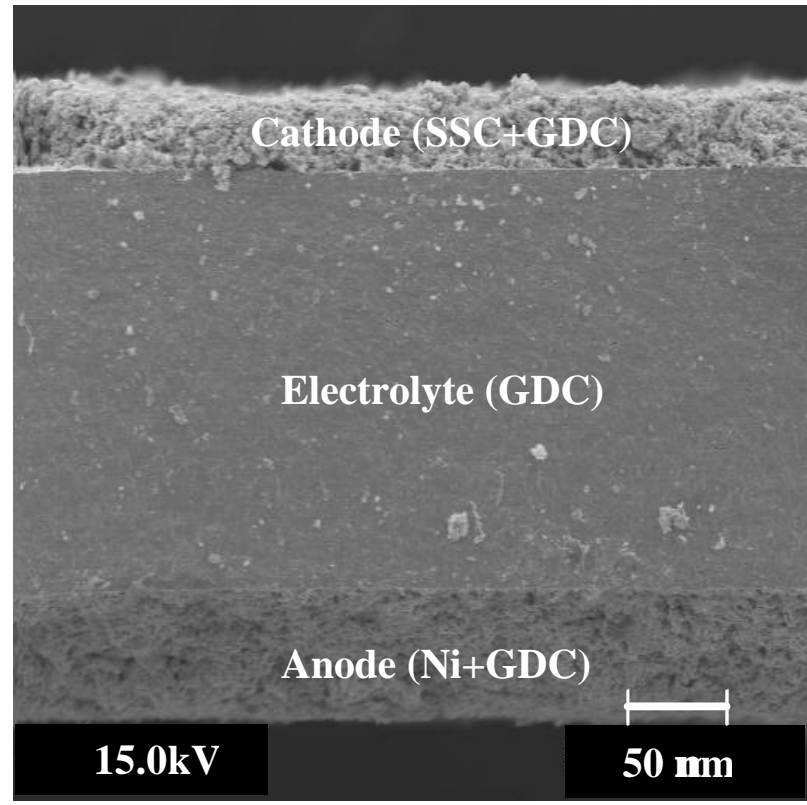

Figure 1. A cross-sectional view (SEM photograph) of a typical electrolyte-supported fuel cell showing 3-layered structure after cell performance measurement. 

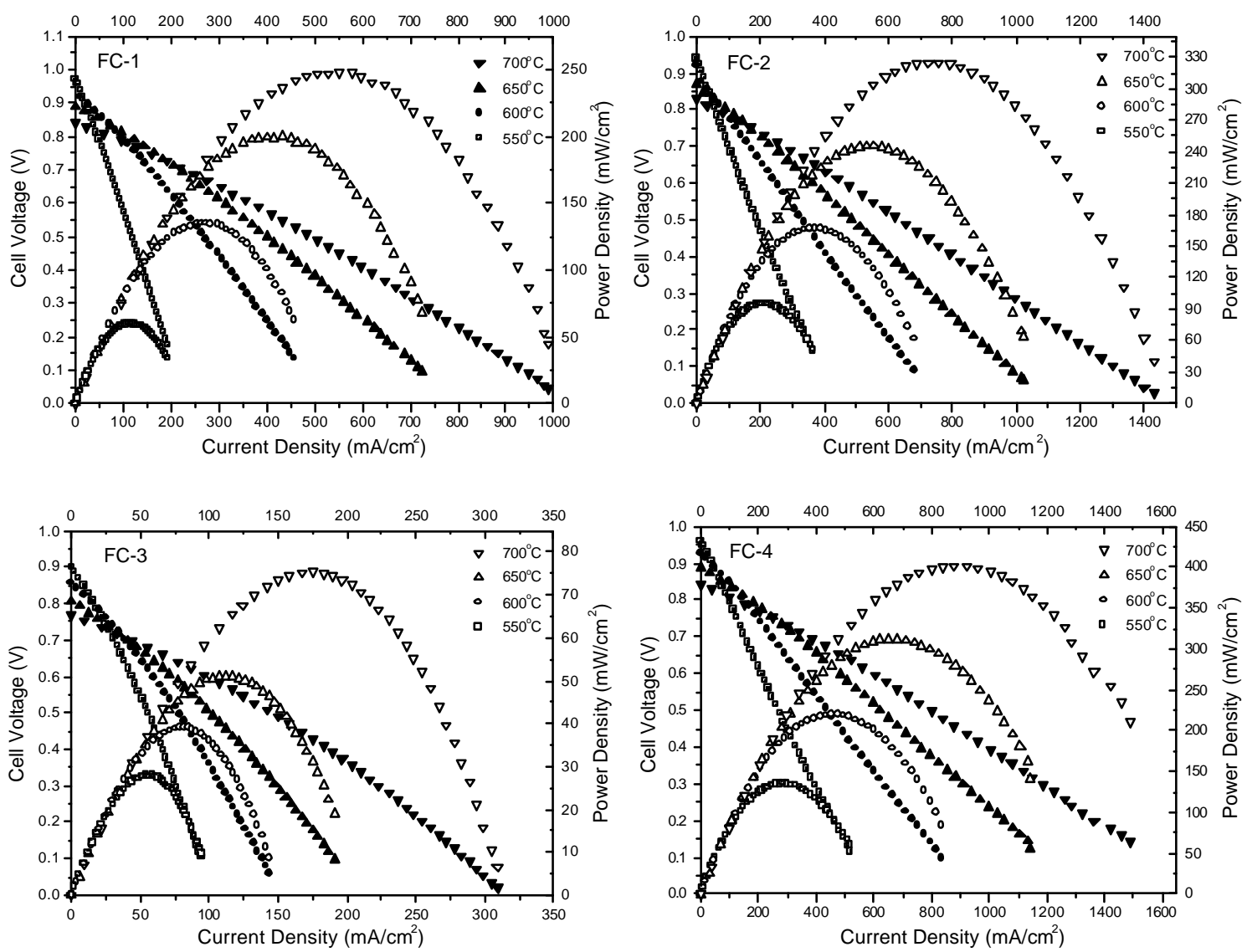

Figure 2. Cell voltages and power densities as a function of operating current density for fuel cells based on different anodes (FC-1 to FC-4 as described in Table 1). 


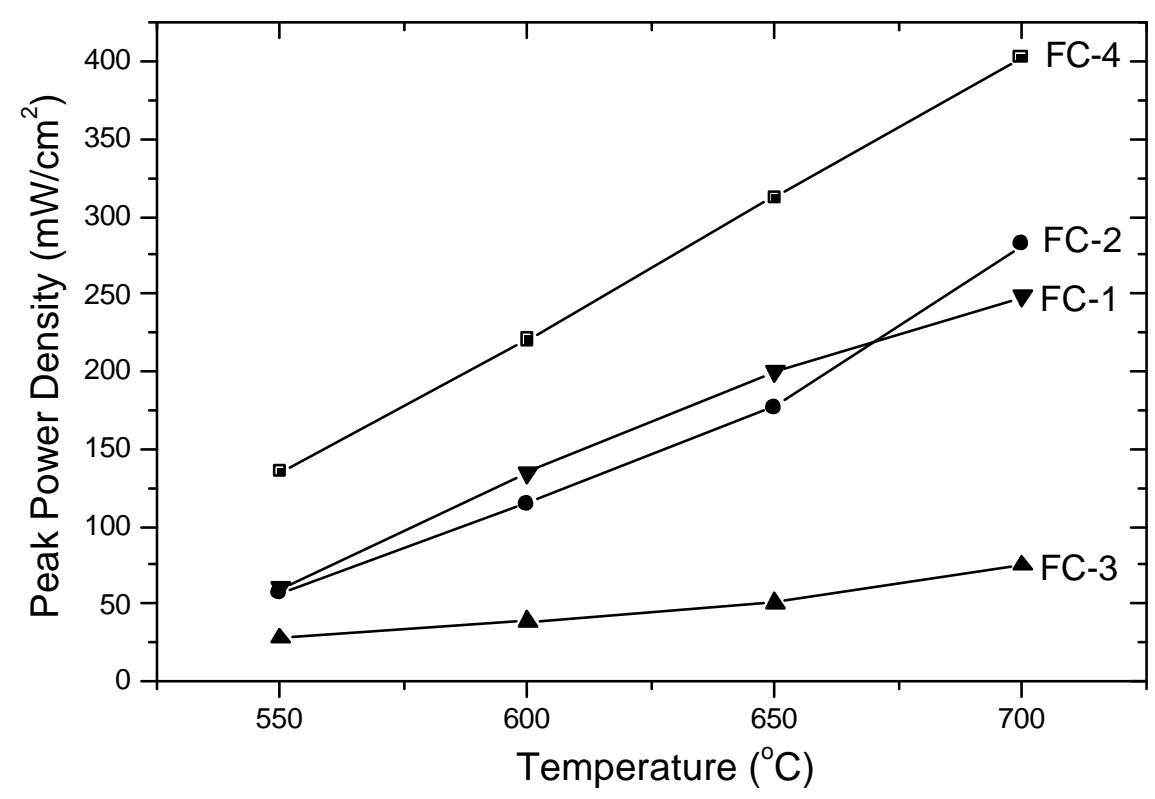

Figure 3. The peak power densities at different operating temperatures for cells FC-1 to FC-4.

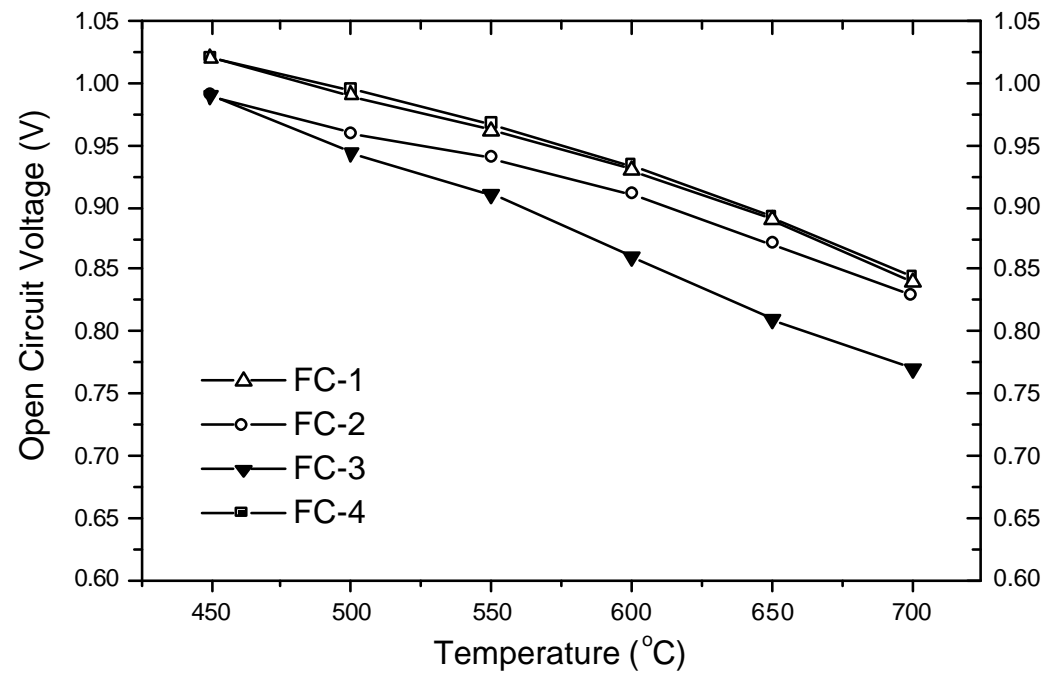

Figure 4. Open circuit voltages of the four cells (FC-1 to FC-4) measured at different temperatures. 

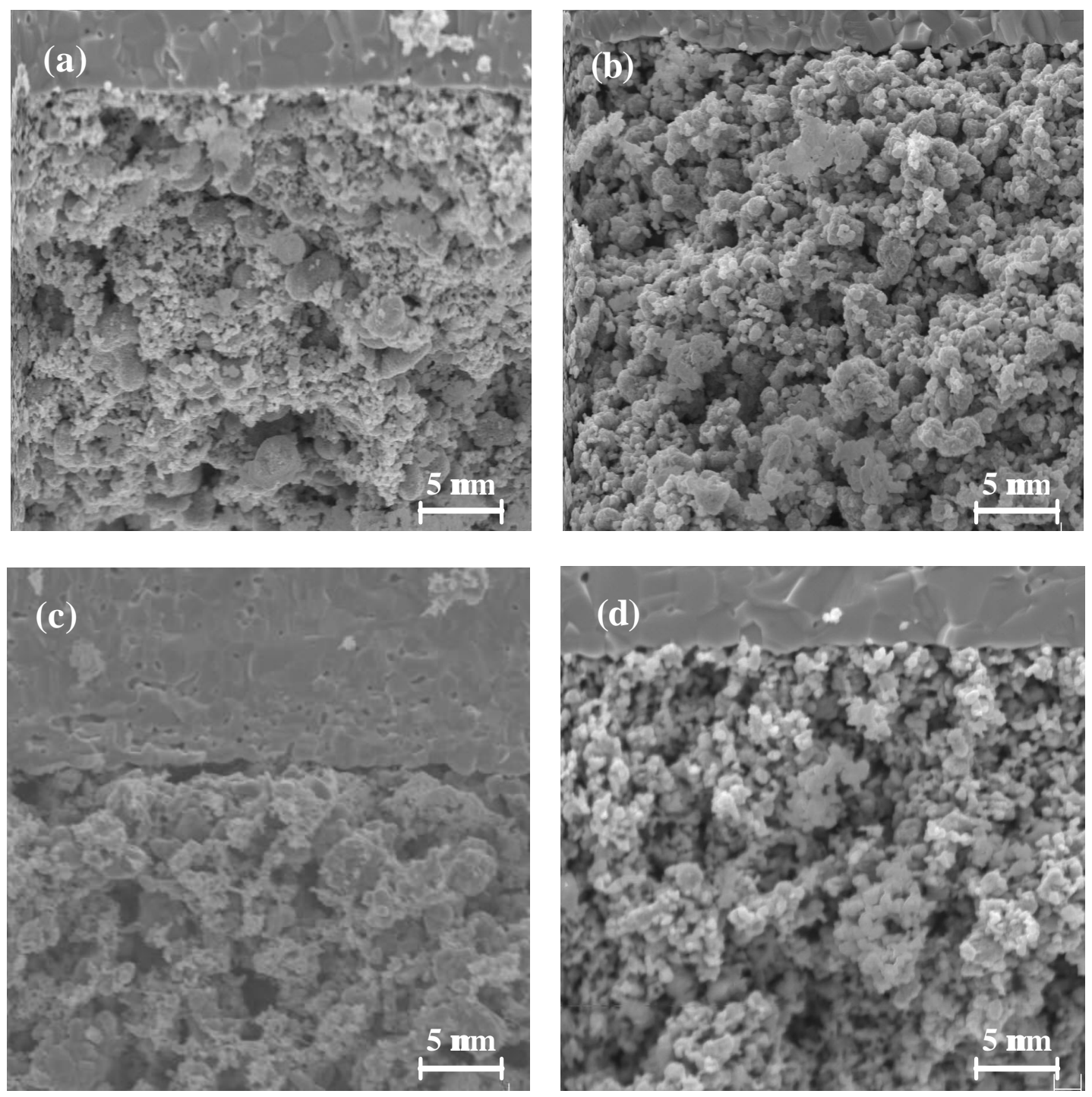

Figure 5. Cross-sectional views (SEM micrographs) of electrolyte and anode components after fuel cell performance testing. The precursor powders for the anodes were (a) commercial $\mathrm{NiO}$ and commercial GDC, (b) GNP NiO and commercial GDC, (c) commercial NiO and GNP GDC, and (d) GNP NiO and GNP GDC, respectively. 


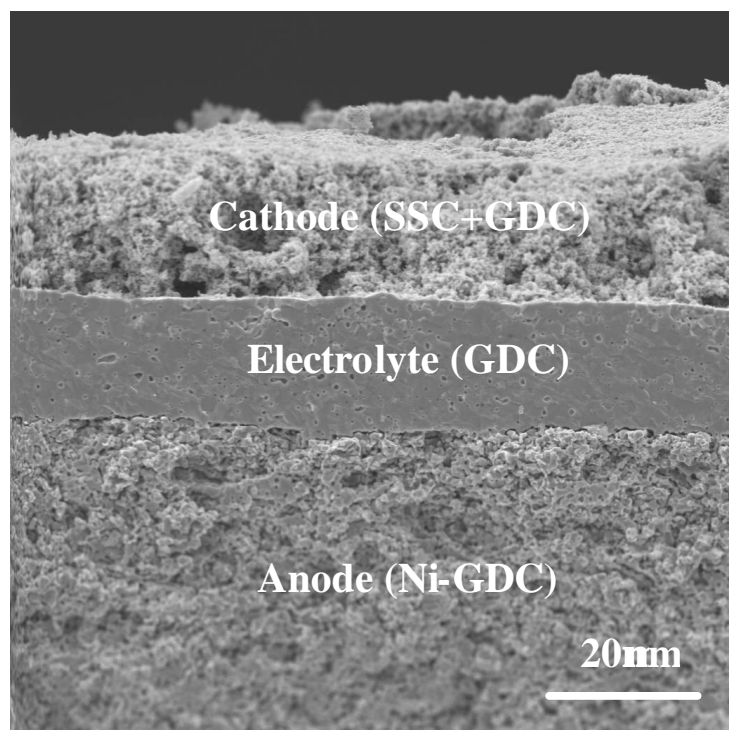

Figure 6. A cross-sectional view (SEM photograph) of a NiGDC anode-supported SOFC with a thin GDC electrolyte layer.
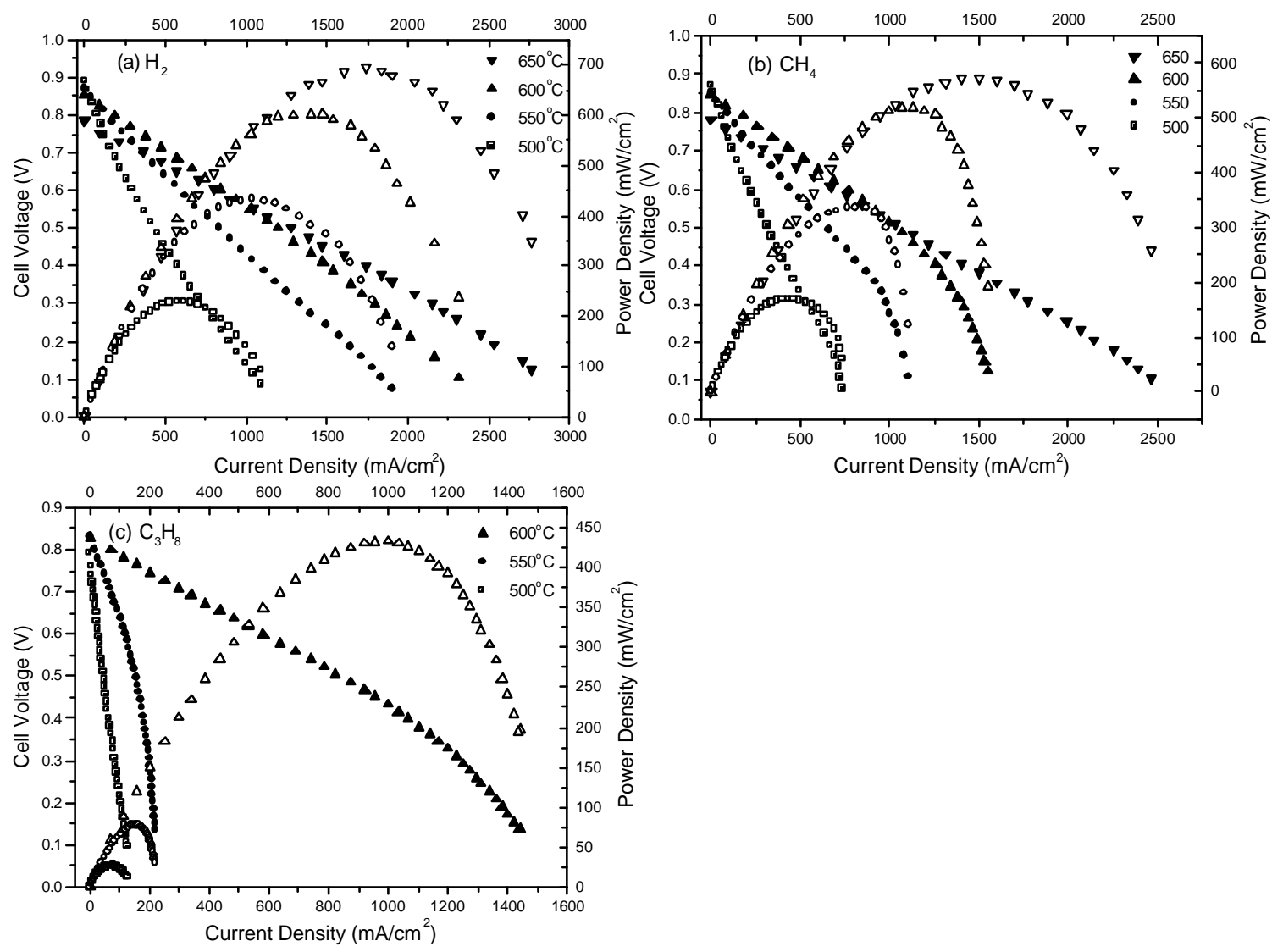

Figure 7. Cell voltages and power densities as a function of current density for a cell with $\mathrm{Ni}$ GDC anode fabricated by co-pressing operated at different temperatures (500 - 650 ${ }^{\circ} \mathrm{C}$ ) with different fuels: (a) $\mathrm{H}_{2}$, (b) $\mathrm{CH}_{4}$, and (c) $\mathrm{C}_{3} \mathrm{H}_{8}$ as the fuel gas. 


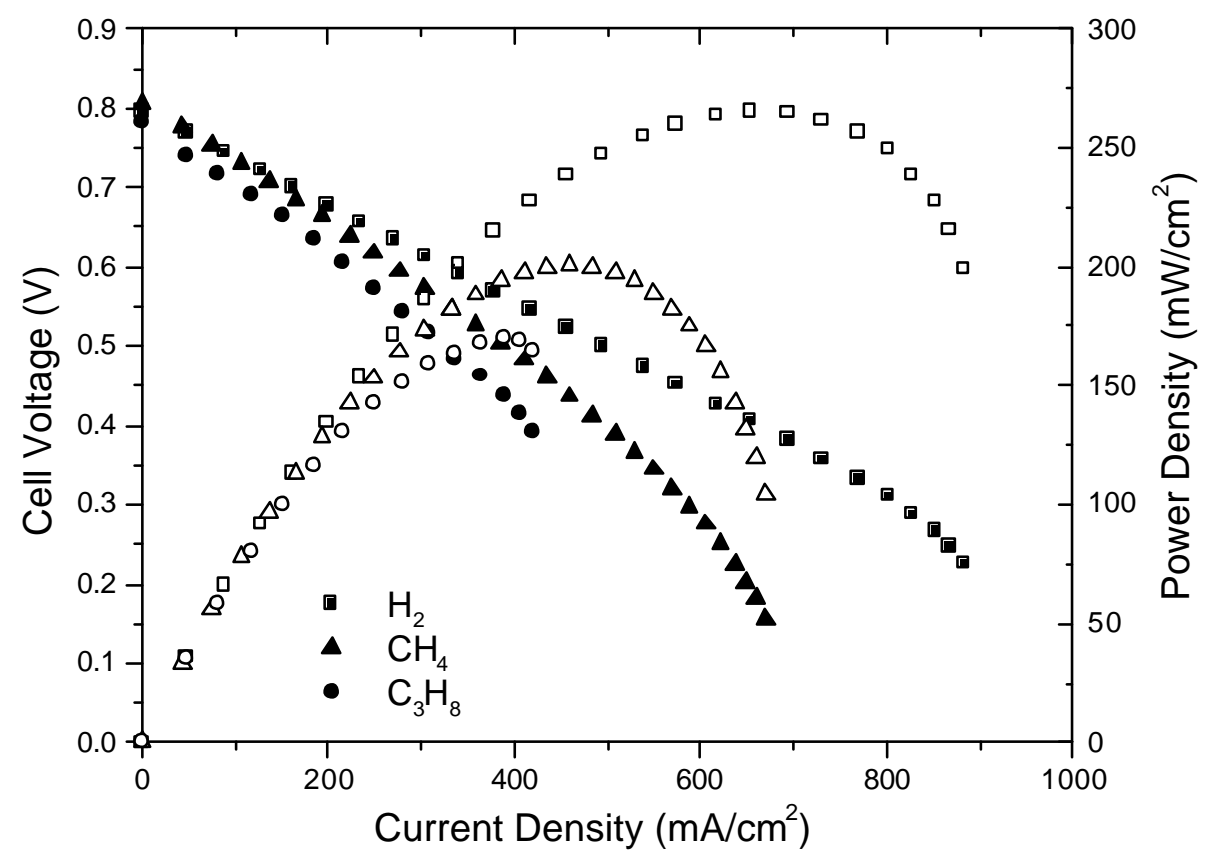

Figure 8. Cell voltage and power density $v s$. current density for a cell with $\mathrm{Cu}-\mathrm{GDC}$ anode by ion-impregnation, measured at $600{ }^{\circ} \mathrm{C}$ when $\mathrm{H}_{2}, \mathrm{CH}_{4}$ and $\mathrm{C}_{3} \mathrm{H}_{8}$ were used as the fuel. 

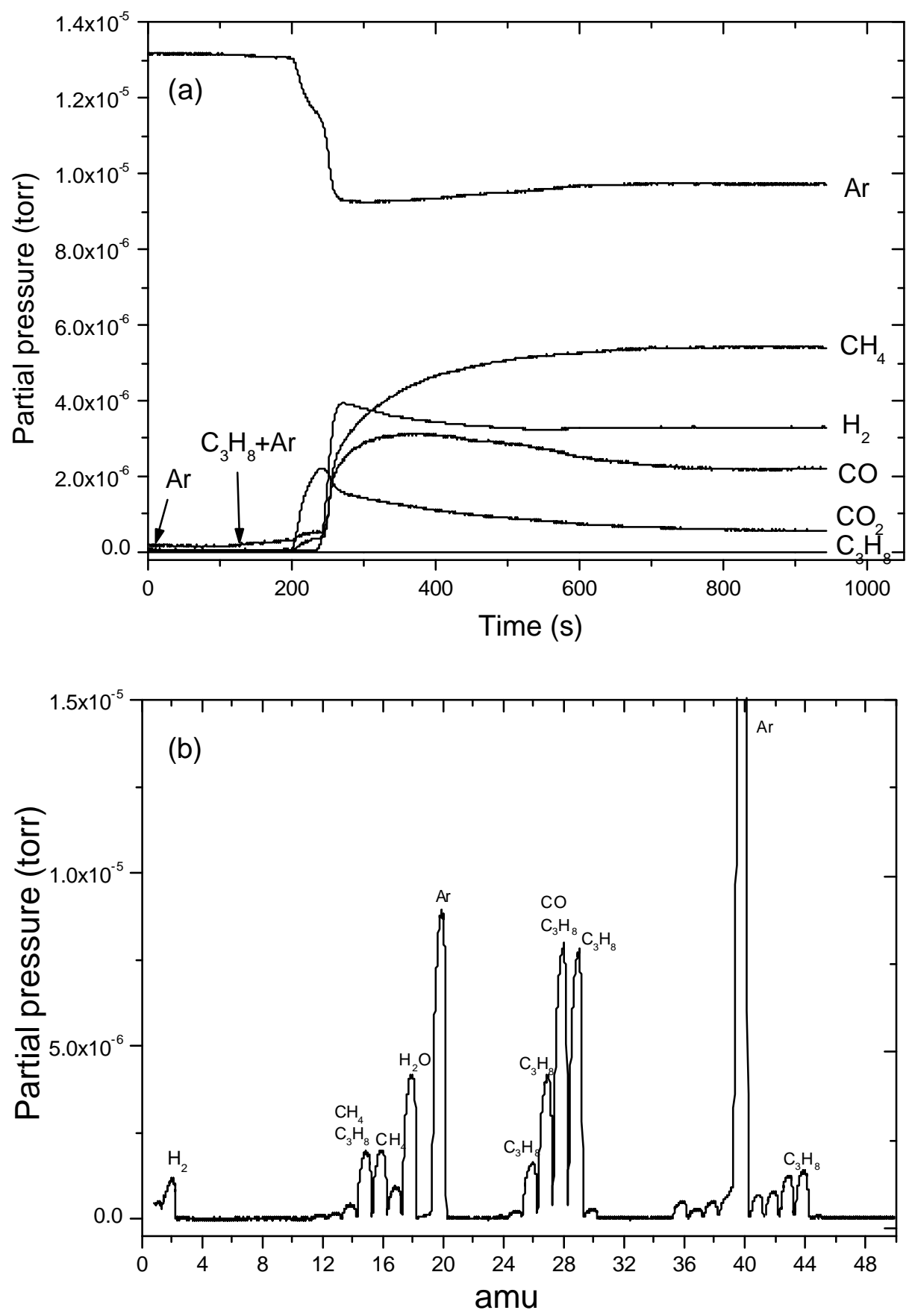

Figure 9. (a) A typical mass spectrum of the reformed propane on catalyst Pt-GDC at $650^{\circ} \mathrm{C}(\mathrm{S} / \mathrm{C}=0.5)$, and $(\mathrm{b})$ mass spectrum of the outlet gas of propane and steam flowing through a heated alumina tube $\left(650^{\circ} \mathrm{C}\right)$ without catalyst. 


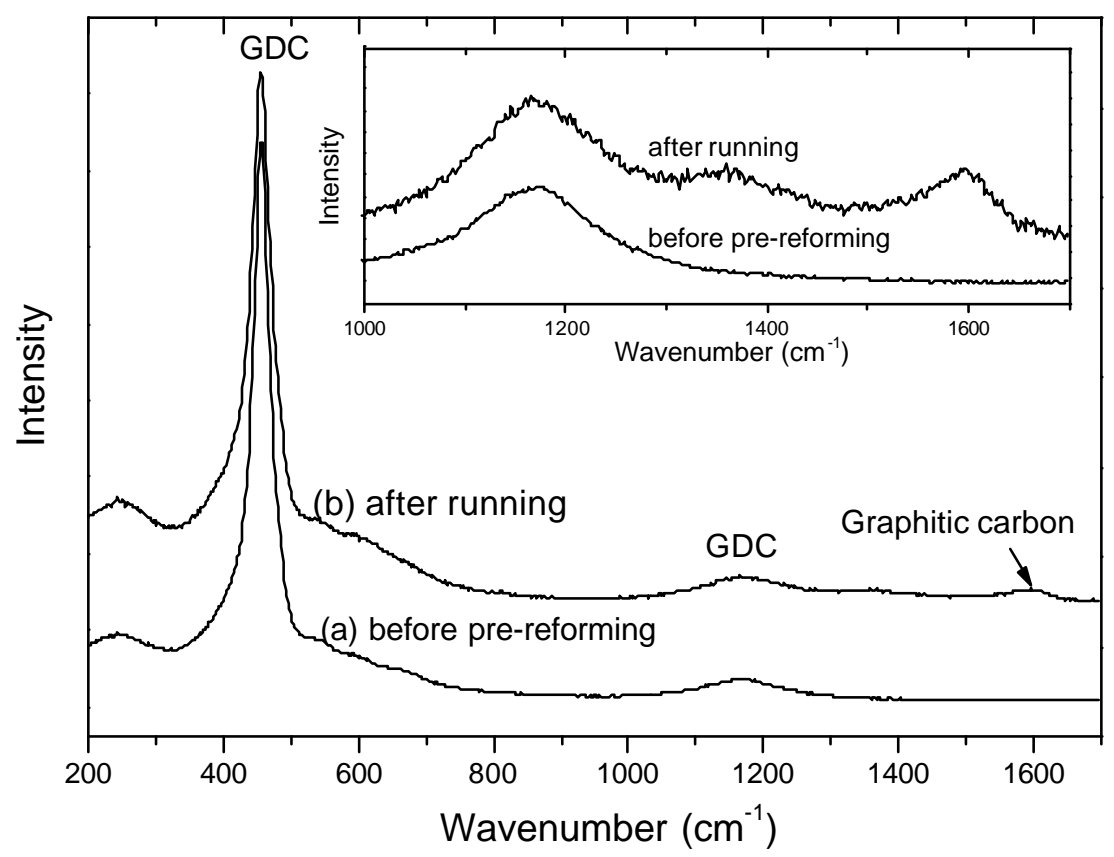

Figure 10. Room temperature Raman spectra of Pt-GDC catalyst (a) before prereforming, and (b) after pre-reforming operation (in the gas entrance area). Insert shows the intensity for wavenumber from 1000 to $1700 \mathrm{~cm}^{-1}$.

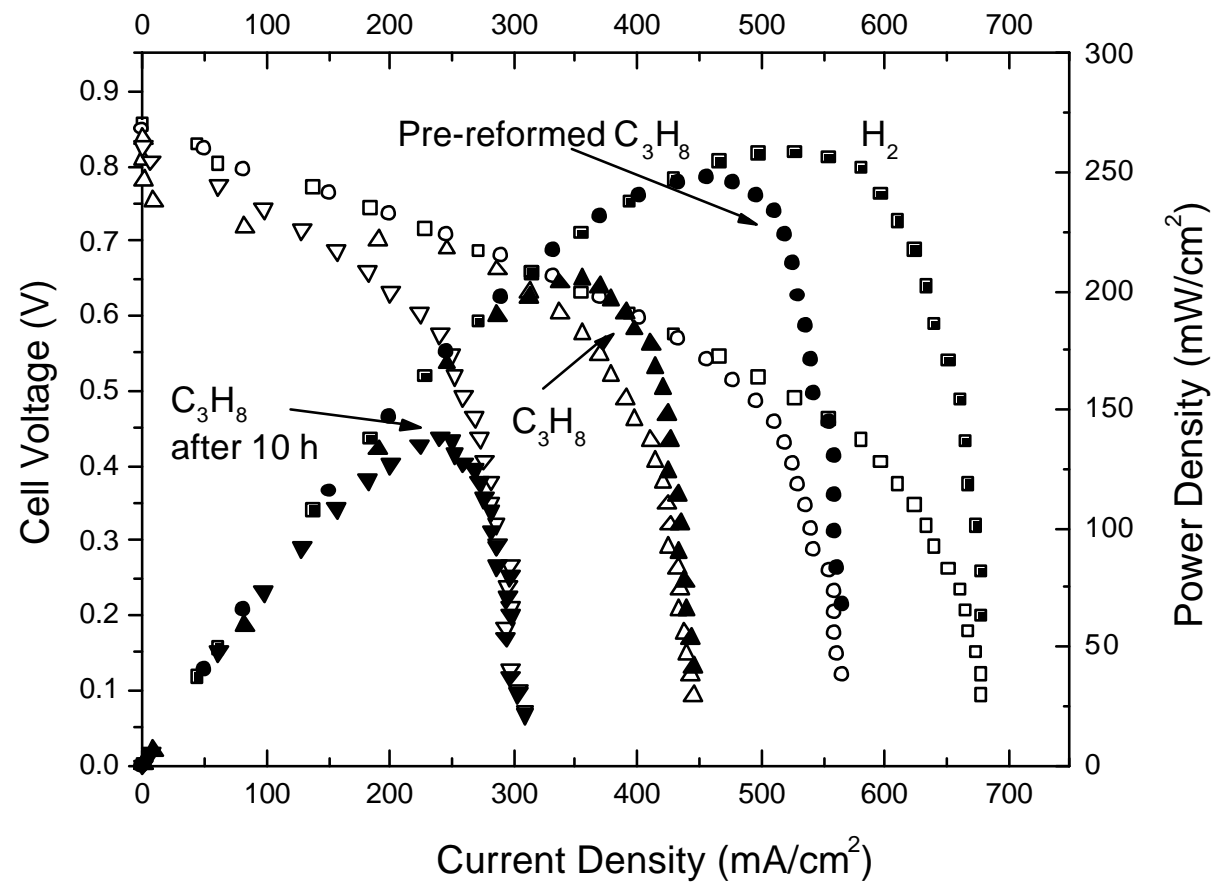

Figure 11. Cell voltages (open symbols) and power densities (solid symbols) as a function of current densities for a fuel cell, $\mathrm{Ni} G D C$ (anode) $/ \mathrm{GDC} / \mathrm{Sm}_{. .5} \mathrm{Sr}_{0.5} \mathrm{CoO}_{3}$-GDC (cathode), at $600^{\circ} \mathrm{C}$ (measured after operating for $0.5 \mathrm{~h}$ ). The data are shown for the following fuels: (0) $10 \mathrm{ml} / \mathrm{min} \mathrm{H}_{2}$ in $10 \mathrm{ml} / \mathrm{min} \mathrm{Ar}$; (o) pre-reformed propane in 20 $\mathrm{ml} / \mathrm{min} \mathrm{Ar}$; and $(\Delta) 5 \mathrm{ml} / \mathrm{min}$ propane in $20 \mathrm{ml} / \mathrm{min}$. 


\section{REFERENCES}

1 Solid State Energy Conversion Alliance (SECA) Workshop Proceedings, Baltimore, Maryland, June 1-2, 2000.

${ }^{2}$ S. de Souza, S. J. Visco, and L.C. De Jonghe, "Reduced-Temperature Solid Oxide Fuel Cells Based on YSZ Thin Film Electrolyte", J. Electrochem. Soc. 144 (1997) L 35.

${ }^{3}$ M. Liu, J. Electrochem. Soc. 144 (1997) 1813-1834.

${ }^{4}$ M. Liu, J. Electrochem. Soc. 145 (1998) 142-154.

${ }^{5}$ R.J. Gorte, S. Park, J.M. Vohs, C. Wang, Adv. Mater. 12 (2000) 1465.

${ }^{6}$ B. de Boer, M. Gonzalez, H. J. M. Bouwmeester, H. Verweij, Solid State Ionics 127 (2000) 269.

${ }^{7}$ S. Park, J. M. Vohs, R.J. Gorte, Nature 404 (2000) 265.

${ }^{8}$ Y. Jiang, A.V. Virkar, J. Electrochem. Soc. 148 (2001) A706.

${ }^{9}$ E.P. Murray, T. Tsai, S.A. Barnett, Nature 404 (1999) 649.

${ }^{10}$ G.A. Tompsett, C. Finnerty, K. Kendall, T. Alston, N.M. Sammes, J. Power Sources 86 (2000) 376.

${ }^{11}$ S. Zha, A. Moore, H. Abernathy, M. Liu, 2003, submitted to J. Electrochem. Soc.

12 M. Liu, "Electrode Kinetics and Transport Properties of Mixed Ionic-Electronic Conductors," in Ionic and Mixed Conducting Ceramics, T. A. Ramanarayanan and H. L. Tuller, Editors, The Electrochemical Society, Pennington, NJ, Vol. 91-12, 191-215 (1991).

${ }^{13}$ M. Liu and A. Joshi, "Characterization of Mixed Ionic Electronic Conductors," in Ionic and Mixed Conducting Ceramics, T. A. Ramanarayanan and H. L. Tuller, Editors, The Electrochemical Society, Pennington, NJ, Vol. 91-12, 95-109 (1991).

${ }^{14}$ K. Otsuka, Y. Wang, E. Sunada, I. Yamanaka, J. Catal. 175 (1998) 152.

${ }^{15}$ O.A. Marina, M. Mogensen, Appl. Catal. A 189 (1999) 117. 